\title{
Comparative Study of Selva and Camarosa Strawberries for the Commercial Market
}

\author{
I. CASTro, O. GonÇAlVES, J.A. TEIXEIRA, A.A. ViCENTE
}

\begin{abstract}
Selva and Camarosa strawberry varieties were characterized chemically and physically. The importance of keeping the stem until processing, the influence of different transport periods under refrigerated conditions, the effects of freezing and exposure to air of damaged surfaces were evaluated. During freezing, losses of ascorbic acid, sucrose, fructose and glucose were reported for both varieties. However, keeping the stem intact minimizes the losses of ascorbic acid in frozen fruits. The exposure to air of cut surfaces affects ascorbic acid content of fresh fruits, with the highest losses reported in Camarosa. Selva showed properties important for commercial use, as compared to Camarosa, with regard to a higher resistance to thawing and higher contents of total phenolics, total protein, and ascorbic acid.
\end{abstract}

Keywords: strawberries, freezing, organic acids, mechanical resistance, water loss

\section{Introduction}

$\mathrm{C}$ ONSUMERS DEMAND HIGH QUALITY JAMS with excellent natural flavor, color, and whole fruit content. Strawberry (Fragaria $x$ ananassa Dutch.) is one of the most perishable fruits, susceptible to mechanical injury, physiological deterioration and decay, due to fungal action, mainly grey mold rot (caused by Botrytis cinerea).

The basic quality of the fruit depends on the interaction of many factors including climate, soil fertility, pest and pathogen control, harvesting time, quality of harvest (fruit integrity, bruising, cutting, for example), and prestorage treatments (Sistrunk and Morris 1985, McLellan 1996).

Preharvest factors affecting postharvest quality of berry crops were studied (Prange and others1997), concluding that most quality parameters are genetically based, so genetic selection is important when specific characteristics are needed (Shaw 1990). Some other studies were made about postharvest strawberry quality, such as the effects of ozone treatment (Pérez and others 1999), the package influence during storage (Sanz and others 1999), and the influence of the atmosphere composition during storage on color stability (Holcroft and Kader 1999). Color stability of strawberry fruit jams, made from frozen strawberries, was shown to be affected by cultivar and storage temperature of the final product (Garcia-Viguera and others 1999). Nevertheless, no studies were found on the appropriateness of Selva strawberries for industrial processing in the fruit puree and jam industry.

Strawberry fruit jams are extremely important in the fruit jams industry because they account for most of the sales. The products that can be made from strawberry jams are extraordinarily different from one another; thus, strawberries have to be prepared in many different ways, such as cut size (from $3 \mathrm{~mm}$ cubes for some pulps to $25 \mathrm{~mm}$ cubes to other fruit preparations) and sugar, color, and flavor additions.

Frozen berries are commonly used for commercially processed jams. The freezing process influences the final quality of the fruit (Suutarinen and others 2000). In fastfreezing, there is insufficient time to remove the water from the cell through osmosis. The cell contents under-cool, and ice forms within the cell. In slow-freezing, there is enough time to remove the appropriate amount of water from the cell and ice does not form within the cell, but outside. On thawing, this may be a source of drip loss and may explain why slow-frozen fruits often have higher rates of drip loss then fast-frozen fruits (Reid 1996).

Evaluating the effects of transportation conditions (including refrigeration and freezing), and analyzing the injuries suffered by the strawberries and their effect on the mechanical and nutritional properties of each variety of strawberries, are the main concerns of the fruit jam industry. The Portuguese fruit jam industry uses mainly 2 strawberry varieties: Selva, grown in Portugal, and Camarosa, imported mostly from Spain.

The main objectives of this study were to characterize chemically and physically 2 strawberry cultivars (CV) that are used in the Portuguese fruit jam industry; to test the importance of keeping the strawberry stem until the jam is made; to evaluate the influence of different transportation periods under refrigerated conditions on physical-chemical properties of the fresh strawberries; to study the effects of freezing on physical-chemical properties of Selva and Camarosa strawberries; to determine the effect of exposure of damaged surfaces to air (such as by cutting) for different periods on physical-chemical properties of fresh strawberries; and to compare the resistance to freezing/thawing of the 2 strawberry varieties in order to evaluate each CV for different commercial products.

\section{Materials and Methods}

TN ORDER TO SIMULATE THE CONDITIONS OF commercial processing, several situations were tested (Figure 1). Selva and Camarosa strawberries were harvested in Bragança (Portugal) and Huelva (Spain), respectively, and transported to the laboratory under refrigerated conditions $\left(4^{\circ} \mathrm{C}\right)$. The fruits were sorted on arrival to eliminate damaged fruits and to select for uniform color and maturation degree (Wang and Lin 2000).

Analyses were conducted 48 and $72 \mathrm{~h}$ after harvesting to check the influence of refrigerated storage time on fruit quality (Boyette and others 1989).

For processing, stems have to be removed. Therefore, after harvesting, the fruit stems were either immediately cut (strawberries without stem) or left intact to be cut in the factory (strawberries with stem). Therefore, samples with and without the stem were tested.

Another commercial procedure is to cut 
the fruits into pieces (usually from 3 to 18 $\mathrm{mm}$ ) so they can be further processed. This cutting operation may be performed at different times prior to additional handling. In order to simulate the cutting operation, fresh strawberries were cut into slices of variable size and left, at room temperature, in contact with air for 5 and 30 min before the analyses were performed.

Whole fresh strawberries, with and without stem, were frozen at $-18^{\circ} \mathrm{C}$ and analyzed after a 6 -mo storage period.

The dripping volume after thawing, which is an important parameter that indicates the fruit's resistance to freezing/thawing, was determined for the 2 varieties tested.

Three replications were made for each parameter and the results presented are mean values with the respective standard deviation.

\section{Determination of $\mathrm{pH}$ and total acidity (TA)}

$\mathrm{pH}$ and TA were determined according to the AOAC 942.15 method (AOAC 1997).

\section{Determination of total solids (TS), volatile solids (VS) and ash}

Samples of approximately $30 \mathrm{~g}$ were placed in an oven at $105^{\circ} \mathrm{C}$ to constant weight, to determine total solids. After that, they were placed at $505{ }^{\circ} \mathrm{C}$ for approximately $1 \mathrm{~h}$ to determine ash (the remnant) and volatile solids content (the difference between TS and ash).

\section{Determination of organic acids}

For the quantification of organic acids, strawberries were blended until forming a puree. Commercial enzymatic kits were used to determine malic acid (kit Boehringer nr 139068), ascorbic acid (kit Boehringer nr 409677), and citric acid (kit Boehringer nr 139076). The kits were obtained from Boehringer, Manheim, Germany. In the case of ascorbic acid determinations, the fruit puree was centrifuged and the supernatant was used, to avoid interferences with the detection method. For each parameter an appropriate dilution was used in ultra-pure water.

\section{Determination of sugar}

For the determination of sugars, a puree was prepared as previously described for organic acids determination. This puree was then filtered through a membrane $(0.2 \mathrm{~mm}$ pore size) and diluted when necessary. Sugars (sucrose, glucose, and fructose) were quantified by HPLC (Chrompack, Middleburg, The Netherlands) using a refractive index (RI) detector (JASCO 830-RI Intelligent RI Detector, Jasco, Tokyo, Japan) and a PL Hi-Plex Ca Column. The eluent was sterilized ultra-pure water. The analyses were made at an elution rate of $0.6 \mathrm{~mL} / \mathrm{min}$ and an oven temperature of $85^{\circ} \mathrm{C}$. The retention times of sucrose, glucose and fructose were, respectively, 11.67, 13.86, and 16.95 $\min$.

\section{Determination of protein}

Protein concentration was measured in the strawberry puree previously described, before and after dialysis, according to the method described by Bradford (1976), using the Pierce (Rockford, Ill., U.S.A.) Coomassie protein assay reagent with crystalline BSA as the standard protein.

Dialysis was conducted by placing approximately $20 \mathrm{~mL}$ of sample into a dialysis membrane of $20 \mathrm{kDa}$ molecular weight cutoff and leaving it for $18 \mathrm{~h}$ at $4{ }^{\circ} \mathrm{C}$ in distilled water.

\section{Determination of fat}

Fat was determined according to the AOAC 983.23 method (AOAC 1997).

\section{Determination of lignin and cellulose}

Lignin determination was made according to the AOAC 949.04 method (AOAC 1997).

Cellulose was determined following the Portuguese standard NP 1005 (1974).

\section{Determination of anthocyanins and total phenolic compounds}

The method described by Riberau-Gayon (1982) was the one used for anthocyanins determination.

Total soluble phenolics in the fruit extracts were determined using the Folin-Ciocalteau reagent according to the method of Slinkard and Singleton (1977).

\section{Determination of drip loss}

Drip loss is defined as the liquid volume (in $\mathrm{mL}$ ) lost per $100 \mathrm{~g}$ of frozen fruits during thawing. The after-thaw volume was determined after $4 \mathrm{~h}$ equilibration at room temperature. Drip loss was calculated by averaging the percentages of liquid losses for each of the 3 replicates made and for each CV.

\section{Statistical analysis}

In order to determine whether the differences found in the various physical-chemical properties analyzed were significant or not, 2-way analysis of variance (ANOVA) was performed at both 5 and $10 \%$ significance levels.

Considering all the combinations of conditions tested in the present work (please refer to Figure 1), it was possible to establish

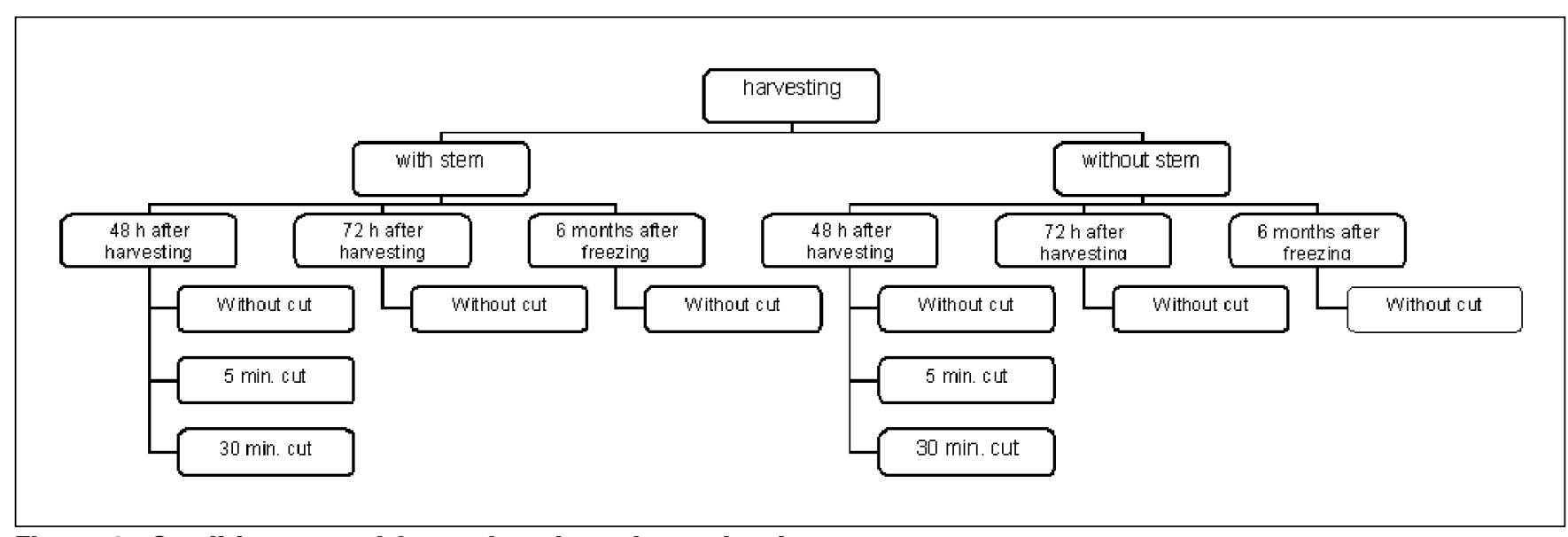


Table 1-Analytical results for Camarosa and Selva whole strawberries 48 and 72 h after harvest, with or without stem.

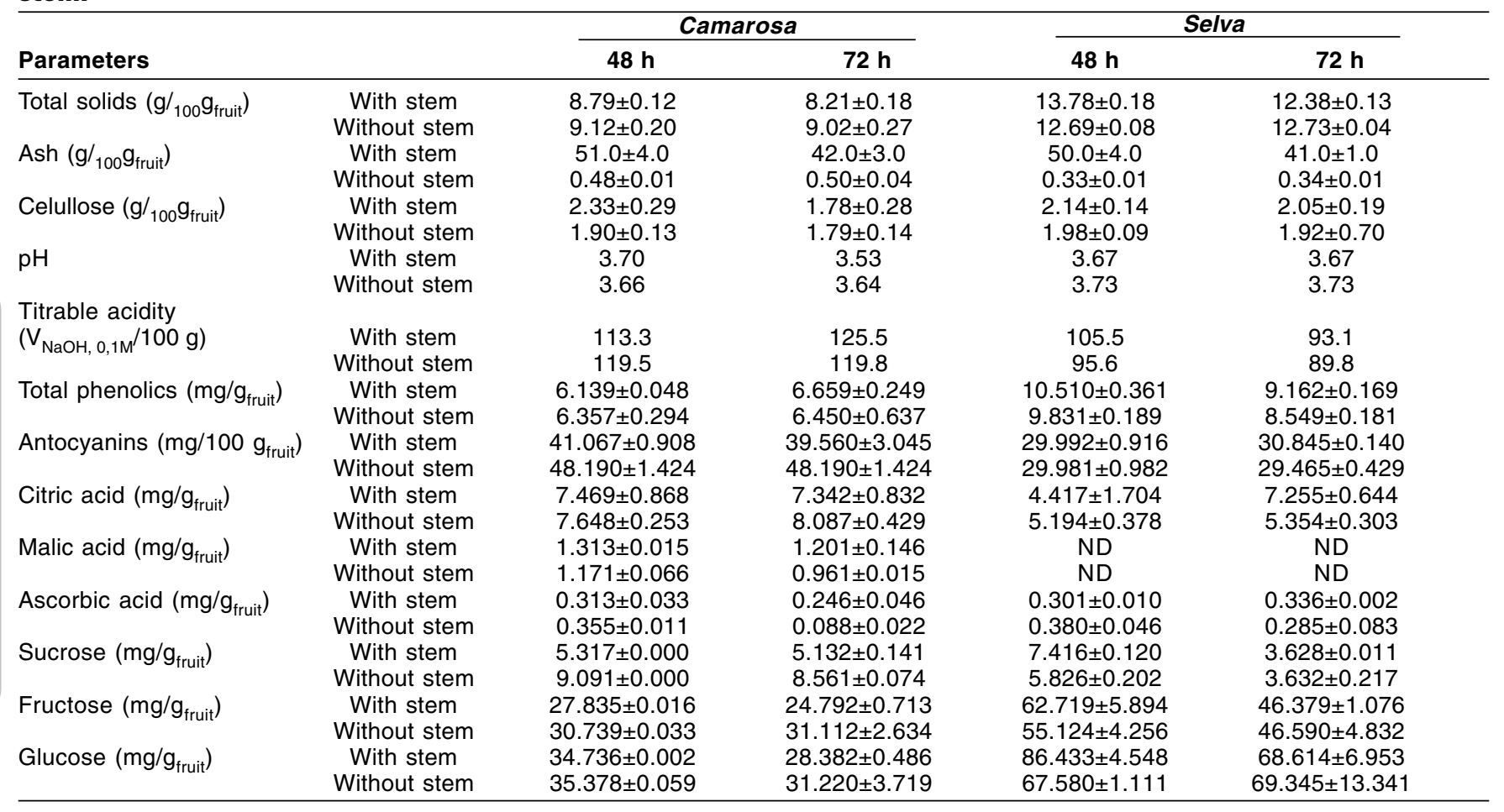

ND - not determined

4 sets of tests to allow comparisons both within the same variety (when subjected to different storage conditions and cutting times) and between the 2 varieties under study (for fresh and frozen fruits). A 1st set of tests was performed to compare, for each variety, 3 different treatments $(48 \mathrm{~h}, 72 \mathrm{~h}$ after harvesting, and 6 mo frozen) and 2 different blocks (with and without stem). A 2nd set of tests was performed, also for each variety, to compare 2 different treatments (5 min and 30 min cut) and the same 2 different blocks (with and without stem). The 3rd and 4 th sets of tests were performed in order to compare the physical-chemical properties of the 2 varieties in fresh and frozen strawberries, respectively and the previously mentioned blocks.

\section{Results and Discussion}

$\mathrm{T}$ HE COMPLETE SET OF RESULTS IS PRESENTed in Table 1 to 4 .

Freezing caused an increase in humidity and, consequently, a decrease in total and volatile solids. This is mainly caused by atmospheric water condensation and freezing on the fruits' surfaces during the freezing process. The freezing process causes damages in vegetable tissues (Reid 1996), raising the free water content (Figure 2 and 3). However, the results of analysis of variance show that the differences found were not significant both at 5 and $10 \%$ significance level. As no significant differences were found for fresh strawberries, for simplicity, the figures represent the averaged results for fresh fruits $(48 \mathrm{~h}$ and $72 \mathrm{~h}$ after harvest, with and without cut, with and without stem).

The fat content of Selva strawberries is nearly half of that of Camarosa, but these values are too low to be relevant when considering its use on commercial products. (Figure 4)

Considering the total phenolics content, no significant differences were found in $\mathrm{Sel}$ va strawberries for all the conditions under study (Figure 1). The same was generally valid for Camarosa berries. When comparing the 2 varieties, Selva strawberries show a higher (30\%) content of total phenolics, which can act as a natural antioxidant agent. This difference is significant at $10 \%$ significance level $(p=0.066)$. Considering the contents of anthocyanins, Selva CV shows a lower content ( $28 \%$ less) than Camarosa, but the differences were found to be not significant at the studied levels $(p>0.1)$. These compounds are responsible for the red color of the fruits, but, for the particular application sought in the present study (industrial use), the color is a secondary parameter once artificial colorants are always added to the products.

The balance among organic acids and sugars determines strawberry flavor (Peréz and others 1999). Of the whole set of experiments made, and concerning the citric and malic acid content of the fruits, the only significant differences $(p<0.1)$ where found when comparing frozen berries from the 2 varieties under study (Camarosa has a higher citric acid and lower malic acid content than Selva).

Ascorbic acid (vitamin C) is present in strawberries, giving an added value to this fruit due to its important nutritional properties. This acid is quite unstable, thus it can be an indication of fruit freshness. In fruit juice processing, as well as in fruit purees and jams preparation, ascorbic acid can suppress browning by avoiding the oxidation of polyphenols to o-quinones that, through polymerization, form brown pigments (Sawamura and others 1994).

In fresh whole Camarosa and Selva strawberries, no differences ( $p>0.1$ ) were found in ascorbic acid levels when comparing the fruits $48 \mathrm{~h}$ and $72 \mathrm{~h}$ after harvesting, both with and without the stem.

In fresh Camarosa strawberries, the exposure of cut surfaces to air induced losses of ascorbic acid as high as $50 \%$ after only $5 \mathrm{~min}$, although after $30 \mathrm{~min}$ the losses were not significantly higher $(\mathrm{p}>0.1)$. Selva showed increasing losses, but they did not exceed $26 \%$ of the initial value. 
Table 2-Analytical results for Camarosa and Selva strawberries 5 and $\mathbf{3 0}$ min after cutting, with or without stem.

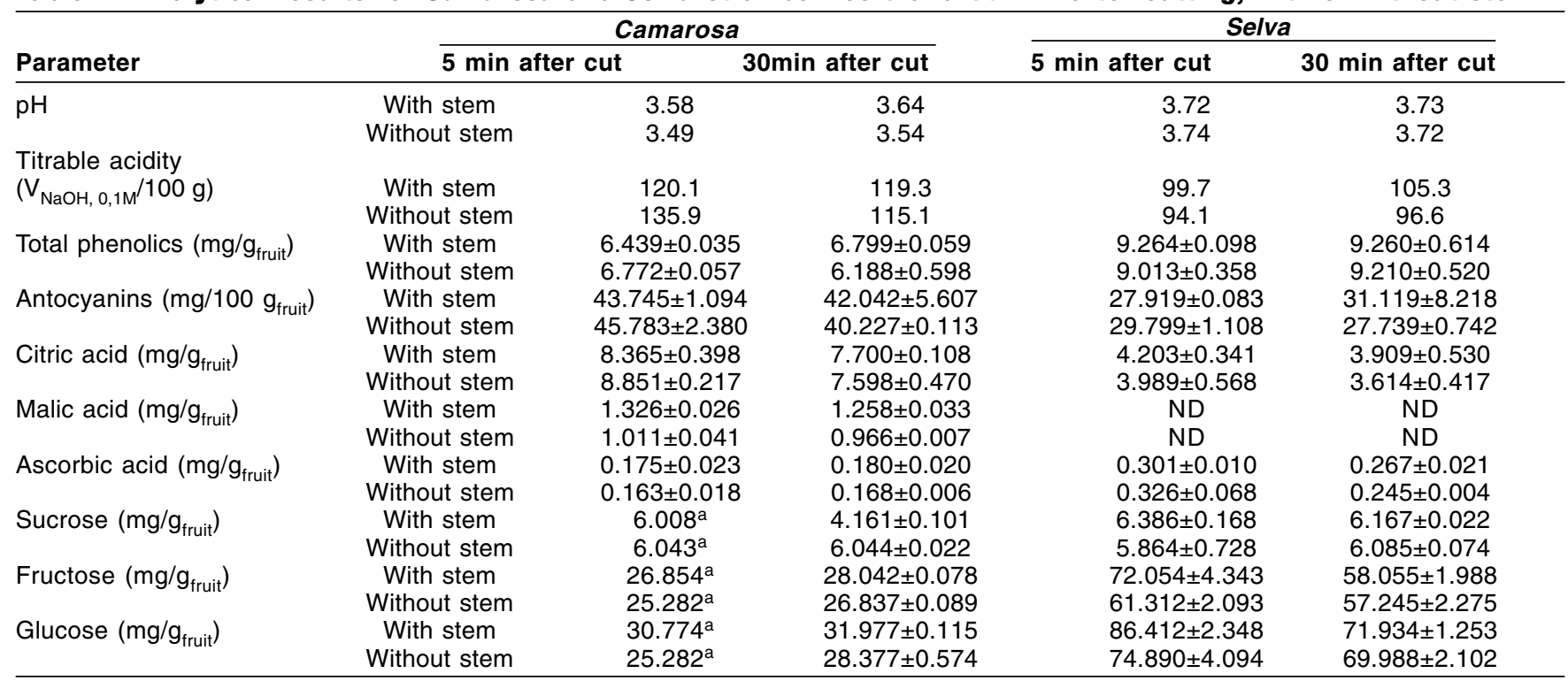

ND - not determined

a These values correspond to a single determination, therefore no SD was calculated.

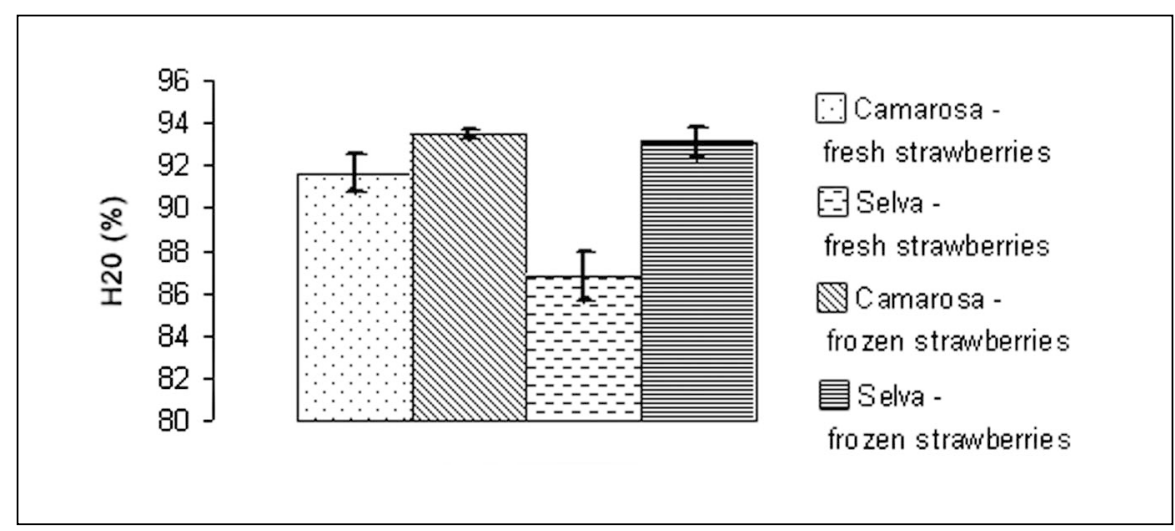

Figure 2-Moisture content $\left(\mathrm{H}_{2} \mathrm{O}\right)$ of fresh and frozen strawberries

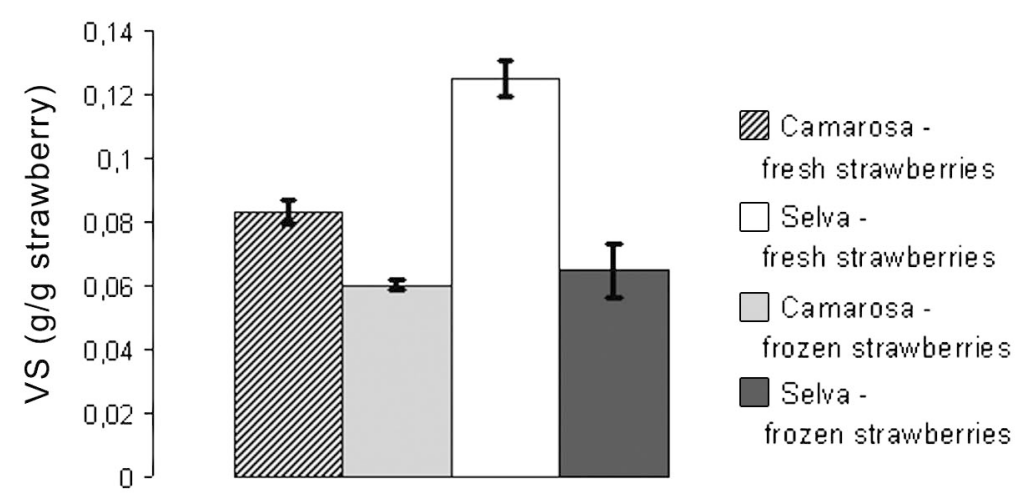

The amount of ascorbic acid is significantly higher (up to 2-fold, $\mathrm{p}=0.047$ ) in frozen Selva strawberries when compared with the Camarosa variety, suggesting advantages of the former in terms of better resistance to oxidizing agents during processing, as well as an increase in the final product shelf life, reducing the need to add preservatives. For strawberry purees and jams, mainly frozen fruits are used. In fact, the freezing process induced a loss of more than $60 \%$ of total ascorbic acid in Camarosa strawberries with stem and more than $80 \%$ when the stem has been previously removed. The corresponding values in Selva were lower ( $22 \%$ and $49 \%$, respectively, for strawberries with and without stem).

The results above are summarized in Table 4 and show that keeping the stem can be of extreme importance to the retention of ascorbic acid in frozen fruits (significant differences, $\mathrm{p}=0.092$, were found when comparing Selva and Camarosa varieties). In fact, the procedure of removing the stem immediately after harvesting is common, but, to our knowledge, the effects of this procedure in the final quality of the fruits have never been demonstrated before.

The liquid volume lost by $100 \mathrm{~g}$ of fruit (drip loss) is an important parameter for industrial processing, not only because it allows to evaluate the quality of the process of freezing/thawing, but also allows to determine the loss of mechanical resistance during these stages, due to cell wall breakage by ice crystals (Reid 1996). Mean values of drip loss after thawing are pre- 
Table 3-Analytical results for Camarosa and Selva whole strawberries after 6 mo of freezing, with or without stem.

\begin{tabular}{lccc}
\hline Parameters & & Camarosa & Selva \\
\hline Total solids $\left(\mathrm{g} /{ }_{100} \mathrm{~g}_{\text {fruit }}\right)$ & With stem & $6.39 \pm 0.09$ & $6.36 \pm 0.50$ \\
& Without stem & $6.68 \pm 0.05$ & $7.4 \pm 0.59$ \\
Ashes $\left(\mathrm{g} /{ }_{100} \mathrm{~g}_{\text {fruit }}\right)$ & With stem & $0.46 \pm 0.02$ & $0.46 \pm 0.63$ \\
& Without stem & $0.52 \pm 0.0003$ & $0.34 \pm 0.02$ \\
$\mathrm{pH}$ & With stem & 3.46 & 3.58 \\
& Without stem & 3.50 & 3.52 \\
Titrable acidity & & & \\
$\left(\mathrm{V}_{\mathrm{NaOH}, 0,1 \mathrm{M} / 100 \mathrm{~g})}\right.$ & With stem & 119.05 & 89.09 \\
Total phenolics $\left(\mathrm{mg} / \mathrm{g}_{\text {fruit }}\right)$ & Without stem & 105.64 & 86.62 \\
& With stem & $8.929 \pm 0.027$ & $9.606 \pm 0.028$ \\
Antocyanins $(\mathrm{mg} / 100 \mathrm{~g}$ fruit & Without stem & $8.325 \pm 0.052$ & $7.739 \pm 0.102$ \\
& With stem & $39.363 \pm 0.419$ & $25.104 \pm 0.052$ \\
Citric acid $\left(\mathrm{mg} / \mathrm{g}_{\text {fruit }}\right)$ & Without stem & $61.363 \pm 1.676$ & $28.993 \pm 0.210$ \\
& With stem & $9.233 \pm 0.538$ & $5.190 \pm 0.088$ \\
Malic acid $\left(\mathrm{mg} / \mathrm{g}_{\text {fruit }}\right)$ & Without stem & $9.265 \pm 0.846$ & $6.147 \pm 0.145$ \\
& With stem & $1.309 \pm 0.195$ & $6.353 \pm 0.697$ \\
Ascorbic acid $\left(\mathrm{mg} / \mathrm{g}_{\text {fruit }}\right)$ & Without stem & $1.181 \pm 0.024$ & $4.920 \pm 0.457$ \\
& With stem & $0.113 \pm 0.015$ & $0.234 \pm 0.009$ \\
Sucrose $\left(\mathrm{mg} / \mathrm{g}_{\text {fruit }}\right)$ & Without stem & $0.063 \pm 0.010$ & $0.168 \pm 0.008$ \\
& With stem & $0.0 \pm 0.0$ & $3.034 \pm 0.060$ \\
Fructose $\left(\mathrm{mg} / \mathrm{g}_{\text {fruit }}\right)$ & Without stem & $0.0 \pm 0.0$ & $2.785 \pm 0.021$ \\
& With stem & $20.146 \pm 0.494$ & $33.587 \pm 0.449$ \\
Glucose $\left(\mathrm{mg} / \mathrm{g}_{\text {fruit }}\right)$ & Without stem & $16.748 \pm 0.970$ & $32.830 \pm 0.369$ \\
& With stem & $19.433 \pm 0.256$ & $35.630 \pm 0.101$ \\
& Without stem & $21.953 \pm 0.668$ & $33.788 \pm 0.357$ \\
\hline
\end{tabular}

ment was visible in thawed strawberry puree.

\section{Conclusion}

Gor both varieties, the Results suggest that until $72 \mathrm{~h}$ after harvest, under refrigerated conditions, there is no deterioration of the main physical-chemical parameters of both the whole and cut fresh fruits.

As compared with Camarosa strawberries, several physical-chemical properties were highlighted for Selva with regard to resistance to thawing, higher levels of total phenolics, total protein, and ascorbic acid content. For the latter parameter, keeping the stem was found to be advantageous when using frozen fruits.

The presented results clearly demonstrate there are advantages associated with the use of Selva strawberries for commercial purposes.

\section{References}

AOAC. 1997. Official methods of analysis of AOAC international. Gaithersburg, Maryland: AOAC In- sented in Figure 5. Selva strawberries present by far the lowest drip loss during thawing, which is in agreement with its higher content in lignin (Figure 6), indicating a higher mechanical resistance. Further, the lower drip loss during thawing determined for Selva variety also helps to explain the lower losses of ascorbic acid detected, after 6 mo of storage at $-18^{\circ} \mathrm{C}$, when compared to Camarosa variety (Nunes and others 1998).

Selva strawberries also show a higher protein content, which can be considered as a nutritional advantage when comparing with the other varieties. On the other hand, Selva and Camarosa strawberries have approximately the same amount of peptides smaller than $20 \mathrm{kDa}$, since the decrease of total proteins after dialysis with a $20 \mathrm{kDa}$ MWCO membrane was approximately the same (Figure 7). This means that Selva's higher protein content is due to high-molecularweight molecules, usually the ones with higher biological activity.

The total sugar content decreases in fresh fruits only slightly until $72 \mathrm{~h}$ after harvesting, but after freezing, sucrose disappeared and glucose and fructose decreased about $50 \%$ and $65 \%$, respectively, for both varieties. This can be explained by fermentation processes that may occur during freezing/ thawing with concomitant consumption of sugars. In fact, although ethanol and aldehydes were not determined, some off odors started to be apparent and gas disengage-

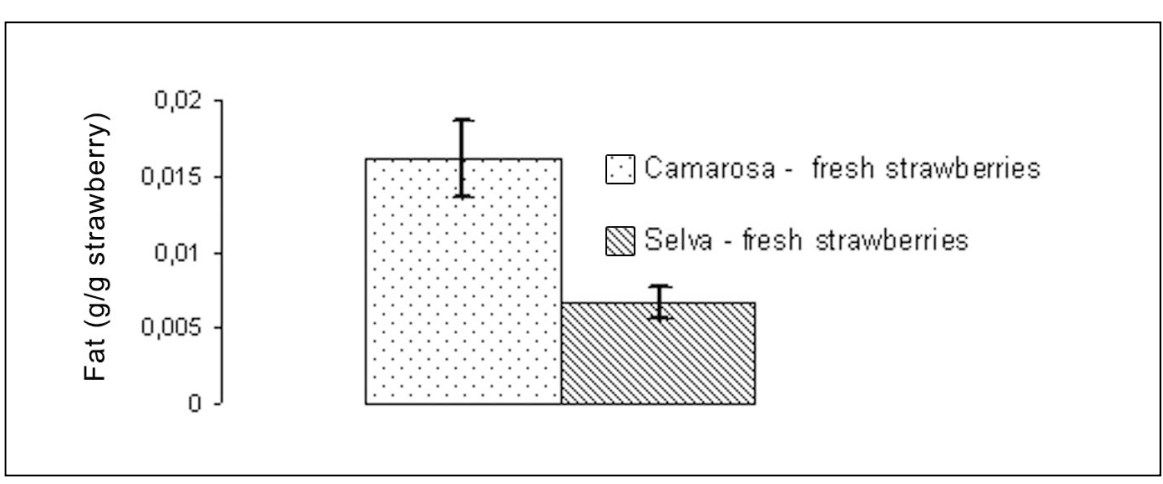

Figure 4-Fat content of fresh strawberries

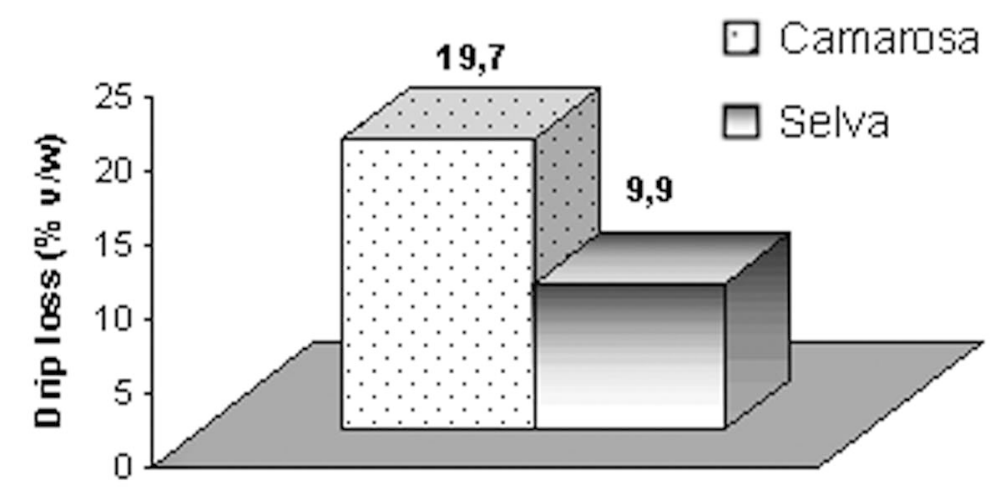

Figure 5-Drip loss of the 2 cultivars of strawberries after thawing 


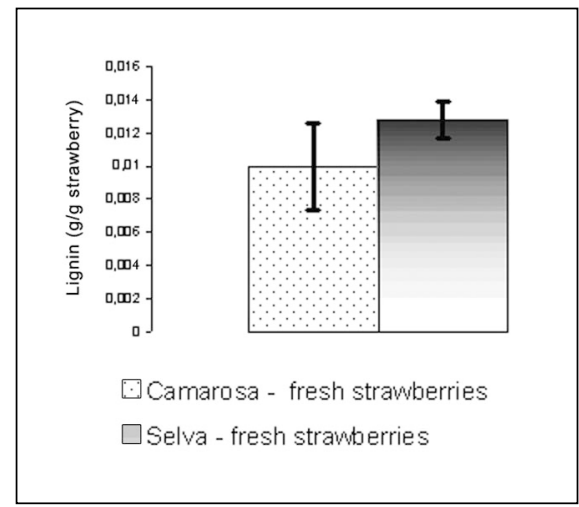

Figure 6-Lignin content of fresh and frozen strawberries

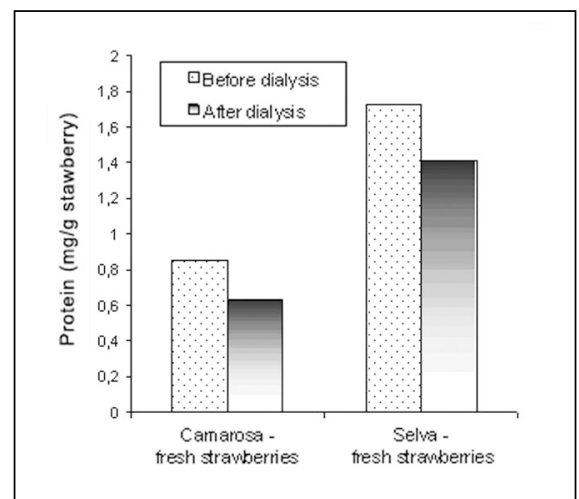

Figure 7-Total protein content of fresh and frozen strawberries, before and after dialysis

ternational.

Bradford, MM. 1976. A rapid and sensitive method for the quantification of microgram quantities of protein utilizing the principle of protein-dye binding. Anal Biochem 72:248-254.

Boyette MD, Wilson, LG, Estes EA. 1989. Postharves cooling and handling of strawberries. North

Table 4-Ascorbic acid losses for Camarosa and Selva strawberries, with or without stem.

\begin{tabular}{lccc}
\hline Ascorbic acid losses (\%) & & Camarosa & Selva \\
\hline After 5 min. cut & With stem & $44 \%$ & $0 \%$ \\
& Without stem & $54 \%$ & $1,5 \%$ \\
After 30 min. cut & With stem & $42 \%$ & $11 \%$ \\
& Without stem & $52 \%$ & $26 \%$ \\
After 6 mo frozen & With stem & $64 \%$ & $22 \%$ \\
& Without stem & $82 \%$ & $49 \%$ \\
\hline
\end{tabular}

Carolina. Agric Ext Serv. Cir :412-413.

Garcia- Viguera C, Zafrilla P, Romero F, Abellán P, Artés F, Tomás-Barberán FA. 1999. Color stability of strawberry jam as affected by cultivar and storage temperature. J Food Sci 64(2):243-247.

Holcroft DM, Kader AA.1999. Controlled atmosphere-induced changes in $\mathrm{pH}$ and organic acid metabolism may affect color of stored strawberry fruit. Postharvest Biol Technol 17:19-32.

McLellan, MR. 1996. Juice Processing. In: LP Somogyi, HS Ramaswamy, YH Hui, editors. Processing fruits: science and technology. Vol. 1: Biology, principles and applications. Lancaster, Pennsylvania: Technomic Publishing Co. P 67-94.

Nunes MCN, Brecht JK, Morais AMMB, Sargent SA. 1998. Controlling temperature and water loss to maintain ascorbic acid levels in strawberries during postharvest handling. J Food Sci 63(6):10331036

Pérez AG, Sanz C, Rios JJ, Olías R, Olías JM. 1999. Effects of ozone treatment on postharvest strawberry quality. J Agric Food Chem 47:1652-1656.

Portuguese standard NP 10005. 1974. Monte da Caparica, Portugal: Instituto Português da Qualidade. Prange RK, DeEll JR.1997. Preharvest factors affecting postharvest quality of berry crops. Hortscience 32(5):824-830.

Reid DS. 1996. Fruit Freezing. In: L P Somogyi, H S Ramaswamy, Y H Hui, editors. Processing fruits: science and technology. Vol. 1: Biology, principles and applications. Lancaster, Pennsylvania: Technomic Publishing Co. P 169-184.

Ribereau-Gayon, P. 1982. The anthocyanins of grapes and wines. In: P Makakis, editor. Anthocyanins as food colors. New York: Academic Press. P 209-244

Sanz C, Pérez AG, Olías R, Olías JM. 1999. Quality of strawberries packed with perforated polypropylene. J Food Sci 64(4):748-752.
Sawamura M, Takemoto K, Matsuzaki Y, Ukeda H, Kusunose H. 1994. Identification of 2 degradation products from aqueous dehydroascorbic acid. J Agric Food Chem 42:1200-1216.

Shaw DV. 1990. Response to selection and associated changes in genetic variance for soluble solids and titrable acids contents in strawberries. J Amer Soc Hort Sci 115:839-843.

Sistrunk WA, Morris JR. 1985. Strawberry quality: influence of cultural and environmental factors. In: H.E. Pattee, editor. Evaluation of quality of fruits and vegetables. Westport, Conn.: AVI. P 217-256.

Slinkard K, Singleton VL. 1977. Total phenol analysis: automation and comparison with manual methods. Am J Enol Vitic 28:49-55.

Suutarinen J, Heiska K, Moss P, Autio K. 2000. The effects of calcium chloride and sucrose prefreez ing treatments on the structure of strawberry tissues. Lebensm Technol 33:89-102.

Wang SY, Lin HS. 2000. Antioxidant activity in fruits and leaves of blackberry, raspberry and strawberry varies with cultivar and developmental stage. J Agric Food Chem 48:140-146.

MS 20010592 Submitted 10/22/01, Accepted 12/31/ 01 , Received 1/10/02

The authors wish to thank Frulact S.A. for supplying of the strawberries. Also, the valuable help of Ana Isabel Ribiero is acknowledged for her work in establishing some experimental protocols. The authors are also grateful to Amélia Dinis for her work in the determination of drip loss.

The authors are with Centro de Engenharia Biológica-I.B.Q.F., Univ. do Minho, Campus de Gualtar, Portugal. Direct inquiries to António Vicente, Univ. do Minho, Dept. de Engenharia Biológica, Campus de Gualtar, 4710-057 Braga, Portugal(E-mail: avicente@deb.uminho.pt). 